\title{
The amino acid composition of rumen-undegradable protein: A comparison between forages
}

\author{
B. Edmunds, ${ }^{* 1}$ K.-H. Südekum,${ }^{* 2}$ R. Bennett,† A. Schröder,‡ H. Spiekers,§ and F. J. Schwarz\# \\ *Institute of Animal Science, University of Bonn, 53115 Bonn, Germany \\ †Adisseo Europe-Africa-Middle East, 92160 Antony, France \\ ¥Kemin AgriFoods Europe, 2200 Herentals, Belgium \\ §Institute for Animal Nutrition and Feed Management, Bavarian State Research Centre for Agriculture (LfL), 85586 Poing, Germany \\ \#Animal Nutrition Weihenstephan, Technical University of Munich, 85350 Freising, Germany
}

\begin{abstract}
The objective of this study was to improve knowledge regarding the amino acid profile of the insoluble portion of ingested forage escaping rumen degradation. Six forage categories were analyzed. Categories varied in botanical composition and each contained 2 samples. Samples within categories were derived from the same parent material but differed in harvest, maturity, or conservation type. The rumen-undegradable protein of all forages was measured by incubation for $16 \mathrm{~h}$ in the rumen of 3 nonlactating cows. All residues were corrected for microbial colonization. The AA profile of the residue was different to the original profile. Degradation trends of individual $\mathrm{AA}$, in terms of increase or decrease relative to the original concentration, were similar between all forages. The AA profiles of forage residues, both within and between categories, were more similar to each other than to their respective original profile. This information may aid in improving the accuracy of estimating postruminal AA supply from forages while decreasing the number of samples required to be analyzed.
\end{abstract}

Key words: ryegrass, white clover, alfalfa, lysine

\section{INTRODUCTION}

Milk protein yield in high-producing dairy cows is often restricted by the first limiting AA (Rogers et al., 1984; Rulquin et al., 1993). In forage-based diets in particular, the majority of the AA requirements are met through the supply of absorbable AA provided by $\mathrm{CP}$ of microbial origin, which is relatively stable in its AA composition. However, as feed intake increases, the proportion of nonmicrobial AA reaching the duodenum

\footnotetext{
Received December 29, 2012.

Accepted April 5, 2013.

${ }^{1}$ Current address: Department of Agriculture and Food, Western Australia, PO Box 1231, Bunbury WA 6231, Australia.

${ }^{2}$ Corresponding author: ksue@itw.uni-bonn.de
}

increases in quantity (Merchen et al., 1986) and importance. Nonmicrobial AA is delivered through endogenous secretions and from proteins, peptides, and free AA of feed origin escaping rumen degradation. This rumen-escaped CP (RUP) may be transported solubilized in the liquid phase or as insoluble particles. The latter is the subject of focus in this study.

Some protein evaluation systems, such as the Dutch (DVE/OEB 2010: Van Duinkerken et al., 2011) and Nordic (NorFor; Volden and Larsen, 2011), assume that the AA composition of RUP is the same as that in the original feedstuff. Although results have been contradictory, it has generally been well proven that the AA profile of feed changes during rumen exposure (Erasmus et al., 1994; van Straalen et al., 1997; Von Keyserlingk et al., 1998). However, to what extent the profile is affected remains an open question and the difficulty of accurate measurement of RUP-AA has maintained use of the original AA profile to estimate duodenal supply. Additionally, the composition of AA from RUP varies depending on its source, meaning that the supply of intestinally absorbable AA can be manipulated by changing the quality of RUP (Seymour et al., 1990). Although the quantity of RUP is also important, an increase will not necessarily translate into improved lactational performance (Santos et al., 1998) if its quality does not meet the requirements of the first limiting AA. Knowledge of the AA profile of RUP is, therefore, essential for accurate diet formulation and precision feeding.

Concentrates usually supply the greater portion of feed AA to the duodenum of high-producing dairy cows. Forages are therefore generally overlooked, although their contribution to AA supply is not insignificant. The main problem lies in the measurement of changes occurring after rumen exposure, which is complicated and laborious. Two previous studies have indicated that after rumen exposure, the $\mathrm{AA}$ composition of grass silage was not remarkably different from that of unensiled grass (González et al., 2009; Edmunds et al., 2013). The idea that either unconserved or ensiled grass 
Table 1. Description of samples and their corresponding N components, including CP, NDIN, ADIN, effective rumen-undegradable CP at a passage rate of $2 \% / \mathrm{h}$ (RUP), and AA-N

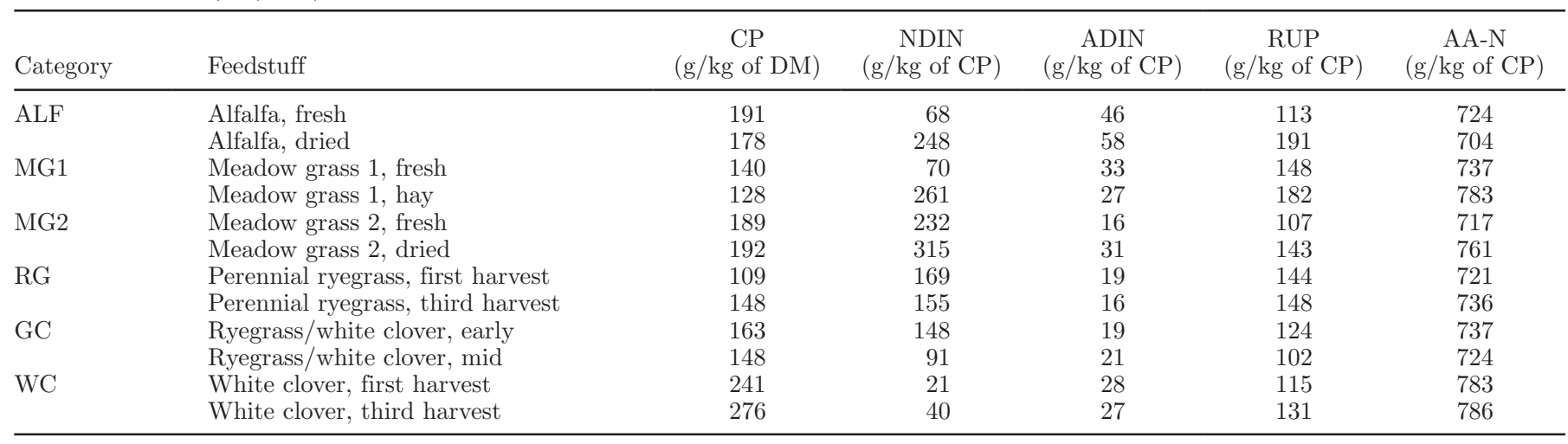

may be used to predict the AA composition of RUP from the same or similar parent material is attractive, as it lowers the number of analyses required. Givens and Rulquin (2004) reported that AA profiles of hay and dehydrated forages are similar to those of fresh forages, with $49 \%$ of variability in forage AA profiles coming from the ensiling process. Based on this and previously stated similarities in the AA profile of RUP between unconserved and ensiled forage, one would also expect similarity between RUP-AA profiles of unconserved and dried forages. The next-highest influencing factor stated by Givens and Rulquin (2004) was forage species. The current study investigated whether this variation (i.e., conservation type and species) also extends to RUP. The results also serve to increase the data bank of AA profiles for RUP of forages.

\section{MATERIALS AND METHODS}

\section{Forages}

From Bavaria, Germany, 12 forages from the 2008 harvest were evaluated for AA before and following rumen incubation using an in situ technique. Six forage categories were used, each containing 2 samples (Table $1)$. The categories were perennial ryegrass (RG), white clover (WC), a ryegrass/white clover sown sward (GC), alfalfa (ALF), and meadow grass from 2 different fields (MG1 and MG2). The 2 samples within each category came from the same parent material and differences are based on either harvest (RG and WC: first vs. third harvest), maturity (GC: early vs. mid bud), or conservation type (MG1: fresh vs. hay; ALF and MG2: fresh vs. artificially dried). A full description of these samples is presented in Edmunds et al. (2012; note: in that publication, 2 ALF and MG2 samples, each for both fresh and artificially dried material, are described; the ALF samples analyzed in the current study are from the third harvest; the MG2 samples only differ in the time spent wilting on the field and the AA profile of both samples from fresh and artificially dried MG2 were almost identical, except for a higher level of Pro in the longer-wilted sample; thus, the profiles were averaged for the current study). All samples and in situ residues were freeze dried. Original material was milled through a 3-mm screen for the in situ trial and through a 1-mm screen for all other analyses. Although the use of fresh material for in situ incubation is desirable, circumstances and equipment prevented this from occurring. Procedures used for the chemical analysis are described in Edmunds et al. (2012).

\section{In Situ Procedure}

A detailed description of the in situ procedure followed was reported by Edmunds et al. (2012). The procedure followed basic guidelines of Madsen and Hvelplund (1994) and used 3 nonlactating German Holstein cows, fitted with rumen cannula. Four bags per feedstuff per cow were incubated for $16 \mathrm{~h}$ on the basis that (1) all rumen-soluble material was assumed to have been solubilized, (2) sufficient material remained after rumen incubation for subsequent analysis, and (3) most other published work from various authors have used this time point. Cows received a diet of (DM basis) approximately and proportionately 0.22 soybean meal and mineral concentrate (approximately 4:1 soybean meal:mineral mix), 0.52 corn silage (CP and NDF: 75.5 and $461 \mathrm{~g} / \mathrm{kg}$ of DM, respectively), and 0.26 grass hay (CP and NDF: 137 and $586 \mathrm{~g} / \mathrm{kg}$ of DM, respectively) daily at 0700 and $1600 \mathrm{~h}$, in 2 equal meals, meeting maintenance ME requirements. The bags were inserted into the ventral rumen directly before the morning feed and were immediately immersed in ice water upon removal. All bags underwent machine washing in cold water and were subsequently freeze dried. Loss of small 
particles from the bags was corrected for using the equation of Hvelplund and Weisbjerg (2000). Residues were pooled on a per-sample basis.

\section{AA Analysis}

The original material and $16 \mathrm{~h}$ in situ residues underwent an AA profile analysis, performed in the Centre d'Analyse, de Recherche et d'Appui Technique (CARAT) laboratory (Adisseo France SAS, Commentry, France). The AA contents were measured by cationexchange chromatography after acid hydrolysis for 24 h (Directive 98/64/CE, 3/09/99 - Norme NF EN ISO 13903, France; European Commission, 1998). Analysis of Met and Cys was performed after initial oxidation of samples with performic acid and Phe was analyzed without hydrolysis and oxidation. Tryptophan was analyzed after hydrolysis in $4 M$ barium hydroxide at $125^{\circ} \mathrm{C}$ for $8 \mathrm{~h}$.

\section{Correction for Microbial Colonization}

A detailed description of the method used to correct in situ residues for $\mathrm{CP}$ added by microbial attachment to feed particles is described by Edmunds et al. (2012). In brief, microbial attachment (MA: $g$ of residue $\mathrm{CP}$ / $\mathrm{kg}$ ) was estimated using the exponential equation of Krawielitzki et al. (2006). The $\mathbf{A}_{\max }$ parameter of the equation, describing the maximum microbial attachment at time $\mathrm{t} \approx \infty$, was estimated by boiling a subsample of the residue in neutral detergent solution to extract microbes (Mass et al., 1999). As this was part of a larger experiment measuring protein degradation in situ, results for these samples were at hand from longer incubations (24, 48, and $96 \mathrm{~h}$ ), which had also undergone treatment with neutral detergent. The difference in CP between the original and neutral detergent solution-treated residue was assumed to be microbial $\mathrm{CP}$ and an average of the 4 incubation times was taken to represent $A_{\max }$, which was then used in the equation of Krawielitzki et al. (2006). In correcting individual AA, the microbial AA profile reported by Storm and Ørskov (1983; fraction $2+3$ ) was used. As not all $\mathrm{N}$ in microbial matter is AA-N, MA was multiplied by a factor of 0.8 (Storm and Ørskov, 1983; NRC, 2001) and the resulting number was multiplied by the published value for each individual AA and then subtracted from the measured concentration of the residue AA as in the following calculation:

$$
\begin{gathered}
\mathrm{AA}_{\text {correct }}(\mathrm{g} / \mathrm{kg} \text { of } \mathrm{DM})=\mathrm{AA}_{i}-[\mathrm{MA} \times 0.8 \\
\left.\times\left(\mathrm{MAA}_{i} / 1,000\right) \times(\mathrm{CP} / 1,000)\right],
\end{gathered}
$$

where $\mathrm{AA}_{i}$ is the measured concentration of the $i$ th $\mathrm{AA}$ from the residue $(\mathrm{g} / \mathrm{kg}$ of $\mathrm{DM}), \mathrm{MAA}_{i}$ is the concentration of the ith AA in microbial matter ( $\mathrm{g}$ of $\mathrm{AA} / \mathrm{kg}$; Storm and Ørskov, 1983), CP is the concentration of residue $\mathrm{CP}(\mathrm{g} / \mathrm{kg}$ of $\mathrm{DM})$, and $\mathrm{MA}$ is as previously described. Summation of individual corrected AA $\left(\mathrm{AA}_{\text {correct }}\right)$ provided the corrected total analyzed AA (TAAA; g/kg of DM) content.

\section{Analytical Calculations and Statistics}

Treatment-based differences between TAAA and between individual AA were analyzed by $t$-test, where treatment was incubation time in the rumen $(0$ or 16 h) and forage samples $(n=12)$ were used as repeats. To compare the likeness of $2 \mathrm{AA}$ profiles of forages and in situ residues, the method of Guilloteau et al. (1986) was used. The method presents the similarity between 2 AA profiles as a singular value: chi-squared $\left(\chi^{2}\right)$. The following formula was used:

$$
\chi^{2}=17 \times \sum_{k-1}^{17}\left(A A_{i k}-A A_{j k}\right)^{2} /\left[\left(A A_{i k}+A A_{j k}\right) / 2\right],
$$

where $\mathrm{AA}_{i k}$ and $\mathrm{AA}_{j k}$ represent the respective amount of AA $k(\mathrm{~g} / 100 \mathrm{~g}$ of TAAA) in forage $i$ and residue $j$. When comparing 2 different forages undergoing the same treatment ( 0 or $16 \mathrm{~h}$ rumen incubation), $i$ and $j$ became forage $a$ and $b$, respectively. Increasing distance of $\chi^{2}$ from 0 indicates decreasing similarity between 2 profiles. Averaged $\chi^{2}$ values within defined classes were analyzed using ANOVA. All statistical analyses were performed using the software package SAS (SAS Institute, 2002) and significant differences were defined at $P \leq 0.05$.

\section{RESULTS}

\section{Chemical Composition of Forages}

The description and chemical composition of the analyzed forages has been presented in detail in Edmunds et al. (2012). The concentrations of DM, CP, ash, crude lipids, fiber fractions, and ME were all within the expected range for their respective feedstuff. Table 1 gives an overview of some of the nitrogenous components from each sample, including CP, RUP, neutral and acid detergent insoluble $\mathrm{N}$, and AA-N. The original AA profiles of MG1, MG2, ALF, and RG, averaged (n $=2$ ) within forage category, match well with published averages for similarly categorized forages (Givens and Rulquin, 2004). The composition of $\mathrm{WC}$ will be discussed later in the paper. 


\section{General Variation in $C P$, Total $A A$, and $A A$ Composition}

Crude protein (g/kg of DM), TAAA (g/kg of DM), and the AA profile $(\mathrm{g} / 100 \mathrm{~g}$ of TAAA) of the original material $(\mathbf{O})$ and from the residue after 16 -h rumen exposure in situ $(\mathbf{R})$ are presented in Tables 2 and 3. The CP and AA content of all residues was corrected for microbial attachment. The CP content of the original material and residue ranged from 109 to 276 and 50 to $174 \mathrm{~g} / \mathrm{kg}$ of $\mathrm{DM}$, respectively. A quantitative difference in TAAA existed between the treatments when expressed in grams per kilogram of DM $[\mathrm{n}=$ 12; mean $(\mathrm{SD})=131.2(27.7)$ and 53.4 (28.8) for $\mathrm{O}$ and R, respectively; $P<0.001$ ]; however, no difference existed when presented as a proportion of $\mathrm{CP}[\mathrm{O}=$ 0.75 (0.04); $\mathrm{R}=0.73$ (0.11); $P>0.05$ ]. This indicates that although the amount of forage AA reaching the duodenum was considerably less than that entering the rumen, the proportion of $\mathrm{AA}$ in relation to $\mathrm{CP}$ was the same. The higher standard deviation of the treatment $R$ value brings this statement into question. The variation was due to the dried ALF (0.97) and first-harvest WC (0.51). It is not clear why this variation exists or whether it is methodologically or biologically related.

Individual AA are presented in grams per $100 \mathrm{~g}$ of TAAA and have been divided into essential + Cys (EAA) and nonessential AA (NEAA). For the EAA, based on the standard deviation $(\mathrm{g} / 100 \mathrm{~g}$ of TAAA; $\mathrm{n}=12$ ) between samples, Lys had the highest level of variation (0.41) in the original material. A higher level of variation between samples came from the NEAA Asp (2.49), Pro (0.88), and Ala (0.67). The highest between-sample variation in the residue came from EAA Lys (0.67), Leu (0.58), and Arg (0.44), and NEAA Gly (1.08), Asp (0.59), and Tyr (0.48). The hay from the MG1 category and the third-harvest WC had the same concentration of Lys in the both the original sample and residue. The general trend of lysine in all other samples was to increase in relation to the original concentration after rumen exposure.

\section{Changes After Rumen Exposure}

Averaged values $(n=12)$ for individual AA concentrations (g/100 g of TAAA) of the 2 treatments (O and $\mathrm{R}$ ) are presented in Table 4 . In all cases, except for Phe, the AA concentration was different $(P<0.05)$ between treatments. The EAA were generally higher after rumen exposure, except Phe, which did not change and Arg, which was lower. All NEAA decreased relative to the original concentration, except Gly and Ser, which increased. Despite a high level of similarity between samples with regard to degradation trends during rumen incubation, often a substantial amount of variation existed in the extent of degradation. A clear example is demonstrated through Lys (Figure 1) where the extent of degradation was not constant between all forages.

Table 2. Crude protein $(\mathrm{g} / \mathrm{kg}$ of DM) and total analyzed AA (TAAA; $\mathrm{g} / \mathrm{kg}$ of DM), and essential (EAA) and nonessential (NEAA) AA (g/100 $\mathrm{g}$ of TAAA) of original forage $(\mathrm{O})$ and residue after 16-h ruminal incubation $(\mathrm{R})$ for perennial ryegrass, white clover, and a grass/clover mix

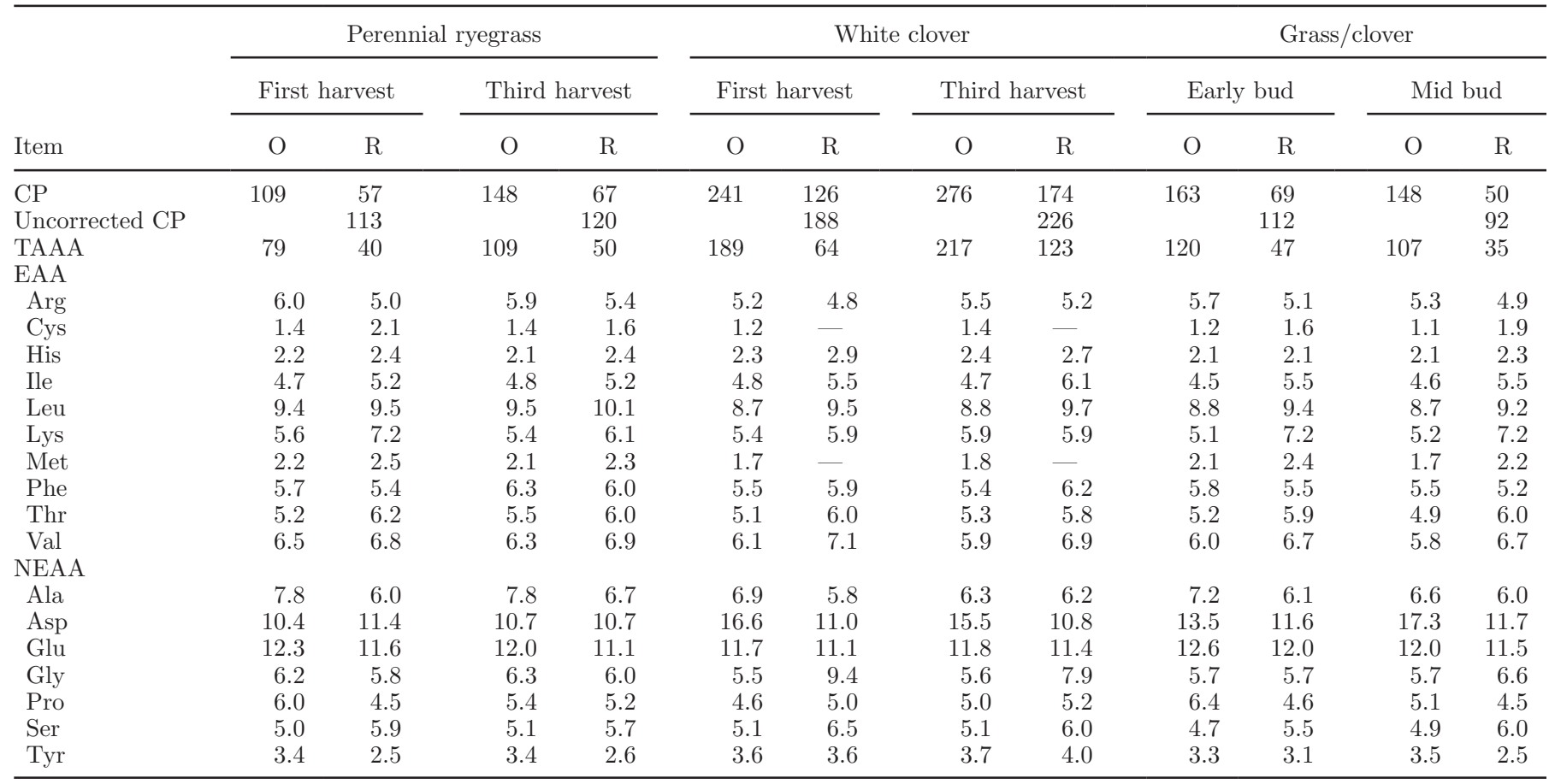


Table 3. Concentrations of $\mathrm{CP}(\mathrm{g} / \mathrm{kg}$ of $\mathrm{DM})$ and total analyzed AA (TAAA; $\mathrm{g} / \mathrm{kg}$ of DM), and essential (EAA) and nonessential (NEAA) AA $(\mathrm{g} / 100 \mathrm{~g}$ of TAAA) of original forage $(\mathrm{O})$ and residue after 16 -h ruminal incubation $(\mathrm{R})$ for meadow grass and alfalfa

\begin{tabular}{|c|c|c|c|c|c|c|c|c|c|c|c|c|}
\hline \multirow[b]{2}{*}{ Item } & \multicolumn{4}{|c|}{ Meadow grass 1} & \multicolumn{4}{|c|}{ Meadow grass 2} & \multicolumn{4}{|c|}{ Alfalfa } \\
\hline & $\mathrm{O}$ & $\mathrm{R}$ & $\mathrm{O}$ & $\mathrm{R}$ & $\mathrm{O}$ & $\mathrm{R}$ & $\mathrm{O}$ & $\mathrm{R}$ & $\mathrm{O}$ & $\mathrm{R}$ & $\mathrm{O}$ & $\mathrm{R}$ \\
\hline$\overline{\mathrm{CP}}$ & 140 & 47 & 128 & 51 & 184 & 81 & 190 & 119 & 191 & 55 & 178 & 73 \\
\hline Uncorrected CP & & 86 & & 102 & & 140 & & 181 & & 72 & & 95 \\
\hline Arg & 5.9 & 5.0 & 5.8 & 6.0 & 5.8 & 5.3 & 5.8 & 5.6 & 5.6 & 4.2 & 5.6 & 5.1 \\
\hline Cys & 1.3 & 1.9 & 1.4 & 1.7 & 1.2 & 1.6 & 1.1 & 1.5 & 1.5 & 1.9 & 1.2 & 1.4 \\
\hline His & 2.3 & 2.4 & 2.0 & 2.2 & 2.1 & 2.3 & 2.2 & 2.3 & 2.5 & 2.3 & 2.4 & 2.4 \\
\hline Ile & 4.7 & 5.1 & 4.7 & 5.2 & 4.8 & 5.6 & 4.8 & 5.3 & 4.9 & 5.2 & 4.7 & 5.3 \\
\hline Leu & 9.0 & 9.8 & 9.2 & 11.0 & 9.3 & 10.0 & 9.2 & 10.2 & 8.7 & 9.0 & 9.0 & 9.4 \\
\hline Lys & 5.9 & 6.7 & 5.0 & 5.0 & 5.0 & 6.3 & 5.3 & 5.9 & 6.2 & 6.9 & 6.0 & 6.4 \\
\hline Met & 2.0 & 2.3 & 2.1 & 2.4 & 2.1 & 2.4 & 2.0 & 2.4 & 1.9 & 2.0 & 1.8 & 2.1 \\
\hline Asp & 12.1 & 11.2 & 10.7 & 10.1 & 10.9 & 10.8 & 10.9 & 10.7 & 12.7 & 12.3 & 12.8 & 11.7 \\
\hline Glu & 12.3 & 11.1 & 12.2 & 11.4 & 12.1 & 11.4 & 13.0 & 11.8 & 11.6 & 11.4 & 11.7 & 11.9 \\
\hline Gly & 5.8 & 6.2 & 6.1 & 6.2 & 6.1 & 6.2 & 5.8 & 6.0 & 5.7 & 6.4 & 5.7 & 6.2 \\
\hline Pro & 5.8 & 4.8 & 7.7 & 5.1 & 6.5 & 5.2 & 6.4 & 5.2 & 6.2 & 5.2 & 6.6 & 4.8 \\
\hline Ser & 4.9 & 5.7 & 4.9 & 5.3 & 4.7 & 5.3 & 4.7 & 5.3 & 5.1 & 6.0 & 5.2 & 5.7 \\
\hline Tyr & 3.4 & 3.1 & 3.4 & 2.6 & 3.3 & 2.6 & 3.6 & 3.1 & 3.6 & 2.6 & 3.7 & 3.2 \\
\hline
\end{tabular}

On the other hand, such variation between forages did not occur for Met (Figure 2) and the extent of degradation appeared to be relatively consistent between most samples.

\section{Comparison of AA Profiles Within Forage Categories}

The $\chi^{2}$ values comparing O-R, O-O, and R-R are presented within forage categories in Table 5 . The closer the $\chi^{2}$ value is to zero, the higher the similarity between 2 profiles. As expected, in all forage categories, $\chi^{2}$ was lowest and close to zero for the O-O comparison $[\mathrm{n}=6$; mean $(\mathrm{SD})=9.3(9.50)$; i.e., between the original material of the 2 samples within each forage category]. The high standard deviation was for MG1 and GC $\left(\chi^{2}=\right.$ 16.5 and 25.5, respectively), which was due to Pro, Lys, and Asp in MG1 and Asp and Pro in GC. The O-R comparisons yielded higher $\chi^{2}$ values $[\mathrm{n}=12$; mean $(\mathrm{SD})=40.1(23.81)]$ than both $\mathrm{O}-\mathrm{O}$ and R-R means $(P<0.05)$. The greatest variation of $\mathrm{R}$ from $\mathrm{O}$ came from both WC samples $\left(\chi^{2}=84.8\right.$ and 51.5 for first and third harvest, respectively) and the GC mid-bud sample $\left(\chi^{2}=80.8\right)$. As residue values for Met and Cys from both WC were missing, the multiplication factor (n) used in the $\chi^{2}$ equation was reduced to 15 ; however, this did not influence the results. The variation can be attributed largely to Asp in all 3 samples, and to glycine in the WC samples alone. Neither WC sample contributed greatly to variation of O-R when considering only EAA. The R-R comparison also yielded low $\chi^{2}$ values $[\mathrm{n}=6$; mean $(\mathrm{SD})=11.2(7.00)]$, indicating that the AA profiles of the 2 residues within each category were more similar to each other than their respective original profile. The high $\chi^{2}$ value from MG1 was due to Lys.

Recalculation of $\chi^{2}$ using only EAA did not alter the order of the means (SD) $[\mathrm{O}-\mathrm{O}=1.3(0.66), \mathrm{O}-\mathrm{R}=8.2$ (4.24), and $\mathrm{R}-\mathrm{R}=4.0$ (3.86)] but, although $\mathrm{R}-\mathrm{R}$ was numerically lower, only $\mathrm{O}-\mathrm{O}$ was different from O-R $(P$ $<0.05)$. The large difference in Lys between MG1 fresh and hay residues resulted in a high $\chi^{2}$ of 11.0 when comparing R-R. Removal of this sample reduced the mean (SD) to 2.5 (1.91), which could then be classed as different $(P<0.05)$ from O-R.

\section{Comparison of Residue AA Profiles Between Forage Categories}

Orthogonal contrasts were used to compare the profiles of the residues between forage categories. Individual AA concentrations of the 2 samples within each category were averaged. Due to the large difference in Lys between MG1 fresh and hay, and the similarity in profiles of MG1 (fresh) and MG2, the MG1 (fresh) profile was combined with both MG2 forages and the mean subsequently calculated. An averaged profile 


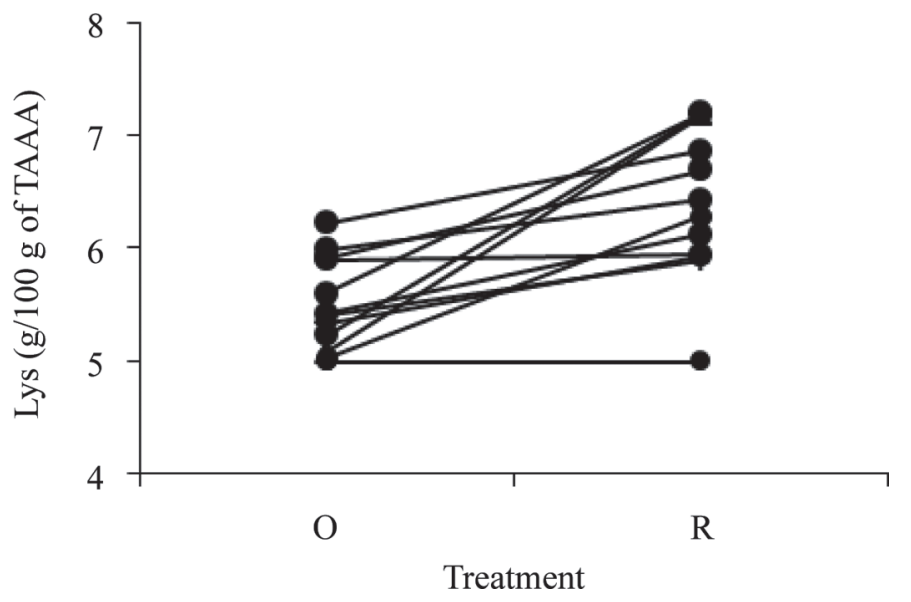

Figure 1. Changes in Lys $[\mathrm{g} / 100 \mathrm{~g}$ of total analyzed AA (TAAA)] from original concentration $(\mathrm{O})$ to after $16 \mathrm{~h}$ rumen incubation $(\mathrm{R})$ from a variety of forages.

of 6 grass silages (Edmunds et al., 2013), which had been analyzed using identical analytical methods, was also included to gain some additional perspective and increase the variety of samples. The $\chi^{2}$ of the O-R comparison for the silage sample was 75.2 (data not shown), indicating a large difference between the original AA profile and rumen-exposed residue. The R-R intercategory $\chi^{2}$ values are presented in Table 6 . All sample pairings, except those including $\mathrm{WC}$ and the grass hay, had $\chi^{2} \leq 7.0$.

\section{DISCUSSION}

Determination of the AA profile of RUP is a laborious process and is not feasible for analysis of large

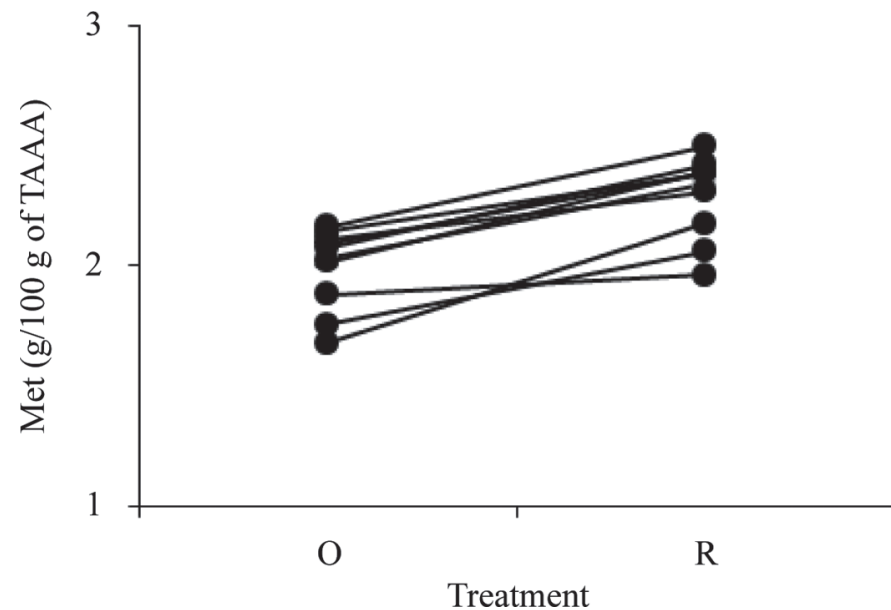

Figure 2. Changes in Met $[\mathrm{g} / 100 \mathrm{~g}$ of total analyzed AA (TAAA)] from original concentration $(\mathrm{O})$ to after $16 \mathrm{~h}$ rumen incubation $(\mathrm{R})$ from a variety of forages.

sample numbers, particularly forages, from which the contribution of RUP is small. The findings of the present study suggest that the AA profile of RUP is similar between forages, which could aid greatly in reducing the number of samples required to be analyzed. The higher $\chi^{2}$ values from the $\mathrm{O}-\mathrm{R}$ comparisons indicate that within each forage category, the AA profiles of the residues of both forages were more similar to each other than their original profile. This applied to all forage categories, indicating that, for the analyzed samples, differences between harvest, maturity, and conservation as hay or by artificial drying did not appear to influence the AA profile of RUP to any re-

Table 4. Mean $(\mathrm{n}=12)$, SD, and CV of total analyzed AA (TAAA; $\mathrm{g} / \mathrm{kg}$ of DM) and essential (EAA) and nonessential (NEAA) AA concentrations (g/100 g of TAAA) of original forage (O) and 16-h rumen residue (R)

\begin{tabular}{|c|c|c|c|c|c|c|}
\hline Item & $\mathrm{O}$ & $\mathrm{SD}$ & $\mathrm{R}$ & $\mathrm{SD}$ & $P$-value & $\mathrm{CV}$ \\
\hline TAAA & 131 & 39 & 58 & 26 & $* * *$ & 35.2 \\
\hline \multicolumn{7}{|l|}{ EAA } \\
\hline Arg & 5.7 & 0.2 & 5.1 & 0.4 & $* *$ & 6.6 \\
\hline Cys & 1.3 & 0.1 & 1.7 & 0.2 & $* * *$ & 12.3 \\
\hline His & 2.2 & 0.1 & 2.4 & 0.2 & $*$ & 7.9 \\
\hline Ile & 4.7 & 0.1 & 5.4 & 0.3 & $* * *$ & 4.2 \\
\hline Leu & 9.0 & 0.3 & 9.7 & 0.5 & $* *$ & 4.6 \\
\hline Lys & 5.5 & 0.4 & 6.4 & 0.7 & $* *$ & 9.3 \\
\hline Met & 2.0 & 0.2 & 2.3 & 0.2 & $* *$ & 8.2 \\
\hline Phe & 5.8 & 0.3 & 5.8 & 0.3 & 0.95 & 5.3 \\
\hline Thr & 5.2 & 0.2 & 5.9 & 0.2 & $* * *$ & 3.0 \\
\hline Val & 6.1 & 0.2 & 6.8 & 0.2 & $* * *$ & 3.5 \\
\hline \multicolumn{7}{|l|}{ NEAA } \\
\hline Ala & 7.4 & 0.7 & 6.3 & 0.3 & $* * *$ & 7.6 \\
\hline Asp & 12.7 & 2.5 & 11.1 & 0.6 & * & 15.2 \\
\hline Glu & 12.1 & 0.4 & 11.4 & 0.3 & $* * *$ & 2.7 \\
\hline Gly & 5.9 & 0.3 & 6.6 & 1.1 & $*$ & 12.6 \\
\hline Pro & 6.0 & 0.9 & 5.0 & 0.3 & $* *$ & 12.2 \\
\hline Ser & 4.9 & 0.2 & 5.7 & 0.4 & $* * *$ & 5.5 \\
\hline Tyr & 3.5 & 0.1 & 2.9 & 0.5 & $* *$ & 11.1 \\
\hline
\end{tabular}

$* P<0.05 ; * * P<0.001 ; * * * P<0.0001$. 
Table 5. Within-category chi-squared values, where $\mathrm{O}$ and $\mathrm{R}$ represent original and residue profiles, respectively ${ }^{1}$

\begin{tabular}{lrrrr}
\hline Item & O-O & ${\mathrm{O}-\mathrm{R}^{2}}^{2}$ & ${\mathrm{O}-\mathrm{R}^{3}}^{2}$ & $\mathrm{R}-\mathrm{R}$ \\
\hline MG1 & 16.5 & 24.3 & 36.7 & 23.5 \\
MG2 & 3.3 & 31.5 & 19.2 & 3.0 \\
ALF & 2.9 & 26.5 & 20.0 & 11.4 \\
RG & 2.8 & 46.4 & 16.0 & 13.5 \\
WC & 4.8 & 84.8 & 51.5 & 8.4 \\
GC & 25.5 & 44.4 & 80.8 & 7.5 \\
Mean & $9.3^{\mathrm{b}}$ & $43.0^{\mathrm{a}}$ & $32.4^{\mathrm{a}}$ & $11.2^{\mathrm{b}}$ \\
\hline
\end{tabular}

${ }^{\mathrm{a}, \mathrm{b}}$ Different letters within a row indicate significant differences $(P<$ $0.05)$.

${ }^{1}$ Due to 12 samples and 6 categories, there are 12 O-R comparisons, where each sample is compared with itself, and $6 \mathrm{O}-\mathrm{O}$ and R-R comparisons, where samples within categories are compared with each other.

${ }^{2}$ Fresh meadow grass 1 and 2 (MG1 and MG2), and alfalfa (ALF), first-harvest ryegrass (RG) and white clover (WC), and early-bud grass/clover (GC).

${ }^{3}$ Dried MG1 and MG2, and ALF, third-harvest RG and WC, and mid-bud GC.

markable degree, except possibly Lys content in hay. A similar observation was also reported for essential AA by González et al. (2009) for ryegrass and its silage and González et al. (2010) for green forage corn and its silage, although in the latter some differences in the content of Arg, Leu, Lys, and Thr were present. The orthogonal contrasts between categories revealed that the high similarity in AA-RUP composition found within forage categories extended to all other analyzed forages except $\mathrm{WC}$ and the grass hay. The MG, RG, GC, and GS forages all contained a high proportion of RG. Interestingly, RUP profiles of both fresh and artificially dried ALF were also similar to the grass profiles. As the degradation of individual AA depends on the susceptibility of the protein they compile, it could be hypothesized that postruminal AA composition is relatively uniform between fibrous feeds.

\section{Changes After Rumen Exposure}

The data shows that AA composition changed as a result of rumen degradation and this observation is strongly supported (Crooker et al., 1986; Varvikko, 1986; Erasmus et al., 1994; van Straalen et al., 1997; Von Keyserlingk et al., 1998). Degradation trends, in terms of proportional increase or decrease of individual AA from their original concentration, were similar among forages. This similarity in trends between forages could be very useful in estimating AA supply from RUP, although it is difficult to find evidence to support this observation due to the low number of published data for forages as well as variation in applied analytical methods. Nevertheless, some comparisons can be made. With lysine, for example, a recurring trend appears between studies of increasing composition after rumen exposure in all forages except hay, for which lysine concentration does not change. Erasmus et al. (1994), who incubated feeds for $16 \mathrm{~h}$ using an in situ technique and corrected for microbial contamination using diaminopimelic acid, observed an increase in lysine concentration for weeping lovegrass and no change for alfalfa hay. González et al. (2001), who also incubated various feeds for 16 $\mathrm{h}$ (in situ) and corrected for microbial attachment using the ${ }^{15} \mathrm{~N}$-intraruminal infusion and solid associated bacteria isolates as the reference sample, also failed to observe a change in lysine for alfalfa hay. González et al. (2009), using the aforementioned method for correcting microbial attachment, observed a slight increase in lysine from Italian ryegrass when estimating effective degradability of individual AA using particle rumen outflow rate $\left(\mathrm{K}_{\mathrm{p}}\right)$. On the other hand, Varvikko (1986), who corrected for microbial attachment using ${ }^{15} \mathrm{~N}$ as a marker and the published values of Storm and Ørskov (1983) for microbial AA composition, observed lysine contents in perennial ryegrass of $6.4,3.6,5.1$, and 5.9 (g/100 g of TAAA) at $0,5,12$, and $24 \mathrm{~h}$, respectively (i.e., an initial decrease and subsequent increase). A similar trend was also observed by Von Keyserlingk et al. (1998) for grass silage $(\mathrm{n}=19)$, whereby lysine concentration $(\mathrm{g} / 100 \mathrm{~g}$ of TAAA) was $6.57,6.02$, and 6.41 at 0,12 , and $24 \mathrm{~h}$, respectively. They used diaminopimelic acid as a microbial marker.

Regarding the hay sample, it may be that the long wilting time coupled with the decreased degradability

Table 6. Between-category chi-squared values of AA profiles after 16-h rumen incubation ${ }^{1}$

\begin{tabular}{lrlrcrrr}
\hline Item & RG & WC & GC & MG, fresh & MG, hay & ALF & GS \\
\hline RG & & 28.2 & 4.3 & 3.1 & 17.5 & 6.8 & 5.7 \\
WC & 28.2 & & 27.1 & 22.1 & 38.6 & 21.2 & 23.7 \\
GC & 4.3 & 27.1 & & 7.0 & 20.1 & 4.4 & 6.9 \\
MG, fresh & 3.1 & 22.1 & 7.0 & & 11.9 & 6.6 & 5.6 \\
MG, hay & 17.5 & 38.6 & 20.1 & 11.9 & & 28.8 & 21.2 \\
ALF & 6.8 & 21.2 & 4.4 & 6.6 & 28.8 & & 5.6 \\
GS & 5.7 & 23.7 & 6.9 & 5.6 & 21.2 & 5.6 & 11.5 \\
Mean & 10.9 & 26.8 & 11.6 & 9.4 & 23.0 & 12.2 & 1.2 \\
\hline
\end{tabular}

${ }^{1} \mathrm{RG}=$ perennial ryegrass; $\mathrm{WC}=$ white clover; $\mathrm{GC}=$ grass/clover; $\mathrm{MG}=$ meadow grass (profile derived from the mean of MG1, fresh, and MG2, fresh and dried); ALF = alfalfa; GS = grass silage. 
of CP from hay could influence Lys degradability to a different degree than other conserved forages. Naturally, it is not possible to draw any conclusions from the single observation in this study; however, as previously mentioned, unchanging Lys was also observed by Erasmus et al. (1994) and González et al. (2001) for alfalfa hay. Additionally, of the 6 silages analyzed by Edmunds et al. (2013), 2 were highly wilted to a DM concentration of $650 \mathrm{~g} / \mathrm{kg}$ of fresh matter; one rapidly wilted in the sun and the other slowly in the shade. The Lys content increased after rumen exposure in all silages except the highly wilted, rapidly dried sample, where no change was observed. Weather conditions during wilting were hot and dry, which were similar to conditions during the making of the hay sample. More investigation into the effect of hay making on Lys content may be of interest.

\section{Species}

The 3 main species investigated here were RG, WC, and ALF. Similarities were strong between the various RG-dominated samples and ALF but not for WC. The original AA profile of the $\mathrm{WC}$ was also dissimilar to published values. White clover has not been as extensively studied and tabulated values are hard to come by. From values that were found (H. Rulquin, INRA, Saint-Gilles, France, personal communication), substantial variations occurred between profiles $\left(\chi^{2}\right.$ $=30.1$, particularly for His, Lys, Val, Asp, and Pro. The 2 WC samples analyzed in this study were from the same parent material and had similar AA profiles; thus, the values presented are associated with a high level of confidence for these particular samples. When presented in grams per kilogram of $\mathrm{CP}$ and compared with tabulated data from Misciattelli et al. (2002), the $\chi^{2}$ was equally as high (32.2) and variation was due mainly to Glu, Pro, and Ser. It is not clear why such variation exists within this species.

\section{Microbial Correction}

The method used in the current study for correcting residues for $\mathrm{CP}$ of microbial origin is novel, although it is based on strong theory and results from various findings (see Edmunds et al., 2012). Development of this new method was required, as no microbial marker was used. The method used for correcting individual AA was similar to that of Varvikko (1986), who also used published values for microbial AA composition. The assumption that microbial AA composition is relatively constant is generally well proven (Weller, 1957; Bergen et al., 1968; Burris et al., 1974; Storm and Ørskov, 1983; Chamberlain et al., 1986). Hildebrand et al. (2011) did observe a significant influence of diet on the AA composition of various microbial fractions measured in vitro; however, this was concluded to be biologically negligible. To test our theory, the published microbial AA profile from Clark et al. (1992) was used to reanalyze our results from MG1, RG, GC, and WC. The order and significance of the $\chi^{2}$ values presented in Table 5 was unchanged (data not shown).

The correction factor of 0.8 , representing the AA-N in bacterial N, as defined by Storm and Ørskov (1983) and used by the NRC (2001), may not be ideal and the review from Clark et al. (1992) using 441 bacterial samples from 35 experiments suggests that AA-N in total bacterial $\mathrm{N}$ averages 0.67 . The proportion of $\mathrm{AA}$ in bacterial $\mathrm{N}$ is affected by the rate of growth of bacteria, with higher growth rates increasing the proportion of nucleic acids (Bates et al., 1985). Higher growth rates are generally associated with high rates of rumen passage. As the cows used for the in situ incubation were on a maintenance ration, with low rates of passage, it may be assumed that the concentration of AA is closer to 0.8 than 0.67 .

Finally, inclusion of the incubation times of 16 and $24 \mathrm{~h}$ in calculating $\mathrm{A}_{\max }$ may be debated, particularly for forages, as some residual B2 protein may be present. Moreover, $16 \mathrm{~h}$ as a mean rumen retention time is probably too short. Longer incubation times may be worth considering for similar trials in the future, particularly when incubating fresh as opposed to dried and ground material in situ. In general, this method of correction is relatively easy and cheap to run; however, more research is required in its improvement and validation.

\section{Buffer-Insoluble AA}

Although somewhat peripheral to this study, the use of buffer-insoluble AA composition as a representative of RUP-AA is an important and affiliated topic. This method is as attractive as it is simple, well standardized, and does not require access to animals. Several studies have shown the profile of insoluble $\mathrm{CP}$ to be a closer representative of RUP than the original profile (MacGregor et al., 1978; Muscato et al., 1983; van Straalen et al., 1997). The Cornell Net Carbohydrate and Protein System (CNCPS; O'Connor et al., 1993) made use of this information, assuming that the AA profile of RUP is the same as insoluble CP. However, insoluble $\mathrm{CP}$ does not provide a direct representation of RUP, as solubility or insolubility of a protein is not by itself an indication of the protein's resistance or susceptibility to hydrolysis by rumen bacterial protease (Mahadevan et al., 1980). As a side experiment to this study, the in situ residues of all 12 samples after 8-h rumen exposure and after in vitro degradation with 
the protease Streptomyces griseus (see Edmunds et al., 2012 for full methodological details) were also analyzed for AA. Using $\chi^{2}$ to compare profiles, the in vitro AA composition was similar to the 8 -h in situ residue (corrected for microbial attachment: $\left.\chi^{2}=11.6 ; P>0.05\right)$, but deviated slightly, but not significantly, from the original $\left(\chi^{2}=28.6 ; P>0.05\right)$ and significantly from the 16 - $h$ in situ profiles $\left(\chi^{2}=42.8 ; P<0.01\right)$. The similarity between in vitro and 8 -h in situ, despite the addition of a protease, is more than likely a reflection of solubility. The difference between profiles at $16 \mathrm{~h}$ indicates that proteolysis in the rumen changes the AA composition of insoluble but rumen-degradable protein.

\section{CONCLUSIONS}

Rumen degradation changes the AA composition of forage. It was observed in this study that the AA composition of RUP was more similar between forages than to their respective original composition. This information can assist in greatly reducing the number of individual samples required to be analyzed to gain more knowledge on the effect of rumen exposure on the AA composition of forages.

\section{ACKNOWLEDGMENTS}

This study was financially supported by the Bavarian Ministry for Agriculture (Munich, Germany); the Institute of Animal Science, University of Bonn (Bonn, Germany); and Adisseo (Antony, France). Thanks go out to M. Schuster and laboratory staff at Bavarian State Research Centre for Agriculture (LfL; Poing, Germany) for the proximate analysis and to E. Devillard, M. Gobert, and technical staff at Adisseo for amino acid analysis.

\section{REFERENCES}

Bates, D. B., J. A. Gillett, S. A. Barao, and W. G. Bergen. 1985. The effect of specific growth rate and stage of growth on nucleic acidprotein values of pure cultures of mixed and ruminal bacteria. J. Anim. Sci. 61:713-724.

Bergen, W. G., D. B. Purser, and J. H. Cline. 1968. Effect of ration on the nutritive quality of rumen microbial protein. J. Anim. Sci. 27:1497-1501

Burris, W. R., N. W. Bradley, and J. A. Boling. 1974. Amino acid availability of isolated rumen microbes as affected by protein supplement. J. Anim. Sci. 38:200-205.

Chamberlain, D. G., P. C. Thomas, and J. Quig. 1986. Utilization of silage nitrogen in sheep and cows: Amino acid composition of duodenal digesta and rumen microbes. Grass Forage Sci. 41:31-38.

Clark, J. H., T. H. Klusmeyer, and M. R. Cameron. 1992. Nitrogen metabolism and amino acid nutrition in dairy cattle. J. Dairy Sci. $75: 2304-2323$.

Crooker, B. A., J. H. Clark, R. D. Shanks, and E. E. Hatfield. 1986. Effects of ruminal exposure on the amino acid profile of heated and formaldehyde-treated soybean meal. J. Dairy Sci. 69:2648-2657.
Edmunds, B., H. Spiekers, K.-H. Südekum, H. Nussbaum, F. Schwarz, and R. Bennett. 2013. Effect of extent and rate of wilting on nitrogen components of grass silage. Grass Forage Sci. http://dx.doi. org $/ 10.1111 /$ gfs.12013.

Edmunds, B., K.-H. Südekum, H. Spiekers, and F. Schwarz. 2012. Estimating ruminal crude protein degradation of forages using in situ and in vitro techniques. Anim. Feed Sci. Technol. 175:95-105.

Erasmus, L. J., P. M. Botha, C. W. Cruywagen, and H. H. Meissner. 1994. Amino acid profile and intestinal digestibility in dairy cows of rumen-undegraded protein from various feedstuffs. J. Dairy Sci. $77: 541-551$.

European Commission. 1998. Commission Directive 98/64/EC of 3 September 1998 establishing community methods of analysis for the determination of amino-acids, crude oils and fats, and olaquindox in feedingstuffs and amending directive 71/393/EEC. Off. J. Eur. Union L 257:14-27.

Givens, D. I., and H. Rulquin. 2004. Utilisation by ruminants of nitrogen compounds in silage-based diets. Anim. Feed Sci. Technol. 114:1-18.

González, J., C. Centeno, F. Lamrani, and C. A. Rodríguez. 2001. In situ rumen degradation of amino acids from different feeds corrected for microbial contamination. Anim. Res. 50:253-264.

González, J., C. Centeno, N. Morujo, J. Faría-Mármol, and A. Martínez. 2009. In situ ruminal amino acid degradability of green and ensiled Italian rye-grass according to particle transit model and microbial contamination correction. Livest. Sci. 123:209-214.

González, J., J. Faría-Mármol, J. M. Arroyo, C. Centeno, and A. Martínez. 2010. Effects of ensiling on in situ ruminal degradability and intestinal digestibility of corn forage. Arch. Anim. Nutr. 64:204-220.

Guilloteau, P., R. Toullec, and J. F. Grongnet. 1986. Digestion of milk, fish and soya-bean protein in the preruminant calf: Flow of digesta, apparent digestibility at the end of the ileum and amino acid composition of ileal digesta. Br. J. Nutr. 55:571-592.

Hildebrand, B., J. Boguhn, and M. Rodehutscord. 2011. Effect of maize silage to grass silage ratio and feed particle size on protein synthesis and amino acid profile in different microbial fractions in a semi-continuous rumen simulation. Animal 5:537-546.

Hvelplund, T., and M. Weisbjerg. 2000. In situ techniques for the estimation of protein degradability. Pages $238-240$ in Forage Evaluation in Ruminant Nutrition. D. Givens and E. Owen, ed. CAB International, London, UK.

Krawielitzki, K., T. Schmidt, J. Voigt, J. Kowalczyk, and M. Gabel 2006. Dynamics of microbial contamination of protein during ruminal in situ incubation of feedstuffs. J. Anim. Feed Sci. 15:313-328.

MacGregor, C. A., C. J. Sniffen, and W. H. Hoover. 1978. Amino acid profiles of total and soluble protein in feedstuffs commonly fed to ruminants. J. Dairy Sci. 61:566-573.

Madsen, J., and T. Hvelplund. 1994. Prediction of in situ protein degradability in the rumen. Results of a European ring test. Livest. Prod. Sci. 39:201-212.

Mahadevan, S., J. D. Erfle, and F. D. Sauer. 1980. Degradation of soluble and insoluble proteins by Bacteroides amylophilus protease and by rumen microorganisms. J. Anim. Sci. 50:723-728.

Mass, R. A., G. P. Lardy, R. J. Grant, and T. J. Klopfenstein. 1999. In situ neutral detergent insoluble nitrogen as a method for measuring forage protein degradability. J. Anim. Sci. 77:1565-1571.

Merchen, N. R., J. L. Firkins, and L. L. Berger. 1986. Effect of intake and forage level on ruminal turnover rates, bacterial protein synthesis and duodenal amino acid flows in sheep. J. Anim. Sci. $62: 216-225$.

Misciattelli, L., T. Hvelplund, M. R. Weisbjerg, J. Madsen, J. Møller, R. Thøgersen, and A. M. Kjeldsen. 2002. Fodermidlernes indhold af aminosyrer og aminosyrernes andel af AAT. Rapport nr. 98. Landbrugets Radgivningscenter, Skejby, Denmark.

Muscato, T. V., C. J. Sniffen, U. Krishnamoorthy, and P. J. Van Soest. 1983. Amino acid content of noncell and cell wall fractions in feedstuffs. J. Dairy Sci. 66:2198-2207.

NRC. 2001. Nutrient Requirements of Dairy Cattle. 7th rev. ed. Natl. Acad. Sci., Washington, DC. 
O'Connor, J. D., C. J. Sniffen, D. G. Fox, and W. Chalupa. 1993. A net carbohydrate and protein system for evaluating cattle diets: IV. Predicting amino acid adequacy. J. Anim. Sci. 71:1298-1311.

Rogers, J. A., J. H. Clark, T. R. Drendel, and G. C. Fahey Jr. 1984. Milk production and nitrogen utilization by dairy cows infused postruminally with sodium caseinate, soybean meal, or with cottonseed meal. J. Dairy Sci. 67:1928-1935.

Rulquin, H., P. M. Pisulewski, R. Vérité, and J. Guinard. 1993. Milk production and composition as a function of postruminal lysine and methionine supply: A nutrient-response approach. Livest. Prod. Sci. 37:69-90.

Santos, F. A. P., J. T. Huber, C. B. Theurer, R. S. Swingle, J. M. Simas, K. H. Chen, and P. Yu. 1998. Milk yield and composition of lactating cows fed steam-flaked sorghum and graded concentrations of ruminally degradable protein. J. Dairy Sci. 81:215-220.

SAS Institute. 2002. User's Guide: Statistics. Version 9.1. SAS Institute Inc., Cary, NC.

Seymour, W. M., C. E. Polan, and J. H. Herbein. 1990. Effects of dietary protein degradability and casein or amino acid infusion on production and plasma amino acid in dairy cows. J. Dairy Sci. 73:735-748.

Storm, E., and E. R. Ørskov. 1983. The nutritive value of rumen micro-organisms in ruminants. 1. Large-scale isolation and chemical composition of rumen micro-organisms. Br. J. Nutr. 50:463-470.
Van Duinkerken, G., M. C. Blok, A. Bannink, J. W. Cone, J. Dijkstra, A. M. Van Vuuren, and S. Tamminga. 2011. Update of the Dutch protein evaluation system for ruminants: The $\mathrm{DVE} / \mathrm{OEB}_{2010}$ system. J. Agric. Sci. 149:351-367.

van Straalen, W. M., J. J. Odinga, and W. Mostert. 1997. Digestion of feed amino acids in the rumen and small intestine of dairy cows measured with nylon-bag techniques. Br. J. Nutr. 77:83-97.

Varvikko, T. 1986. Microbially corrected amino acid composition of rumen-undegraded feed protein and amino acid degradability in the rumen of feeds enclosed in nylon bags. Br. J. Nutr. 56:131140 .

Volden, H., and M. Larsen. 2011. Digestion and metabolism in the gastrointestinal tract. Pages 59-80 in NorFor-The Nordic Feed Evaluation System. H. Volden, ed. Wageningen Academic Publishers, Wageningen, the Netherlands.

Von Keyserlingk, M. A. G., J. A. Shelford, R. Puchala, M. L. Swift, and F. J. Fisher. 1998. In situ disappearance of amino acids from grass silages in the rumen and intestines of cattle. J. Dairy Sci. 81:140-149.

Weller, R. A. 1957. The amino acid composition of hydrolysates of microbial preparations from the rumen of sheep. Aust. J. Biol. Sci. $10: 384-389$ 